\title{
Modern use of historical architectural objects of Botanical gardening (foreign experience)
}

\author{
Olga Belousova ${ }^{1, *}$ \\ ${ }^{1}$ Saint Petersburg state University of architecture and civil engineering, 2-ya Krasnoarmeyskaya \\ Street, 4, 190005, Saint Petersburg, Russia
}

\begin{abstract}
Studying the experience of European countries that have influenced the development of world botanical architecture, such as Italy, France, Belgium, Austria and Germany, in the field of restoration and use of these historical structures, can serve as a basis for choosing alternative ways of functional use of historical greenhouses in St. Petersburg. A historical analysis of changes in the basic function of greenhouses has been carried out, which allowed us to identify two groups of causes: global and local. The beginning of active work on the restoration and reconstruction of historical greenhouses, as well as options for their adaptation to modern conditions. 64 historical greenhouses located on the territory of botanical gardens, as well as on the territory of palace and park ensembles, estates and villas of selected European countries were considered for modern use. This allowed us to distinguish three directions of their functional use: preserving the basic botanical function; changing the basic botanical function; and combining various functions. The architectural and townplanning features of the object are considered, taking into account the location on the site, the geometric characteristics and material of the greenhouses, as well as the architectural and environmental impression, taking into account the new functional use.
\end{abstract}

\section{Introduction}

Greenhouses are architectural objects of botanical gardening. During the 17th and 19th centuries they played an important role - the formation of prestige on the world stage, both in Europe and Russia in the field of landscape art and botanical gardening. These structures have passed a complex historical path in the development of their spatial planning and design solutions, which were influenced by various factors, one of them was the basic botanical function - the preservation, maintenance and demonstration of various exotic plants. It is the basic botanical function that plays the main role in creating a special architectural and environmental perception and psychoemotional impression.

Greenhouses become objects of pride and competition not only between owners who competed with each other in the decoration of gardens, but also cities that seek to excel in this area (by 1887, Belgium and the Netherlands had already built water greenhouses, which affects their construction in Lyon). Greenhouses determined the status of the city and

\footnotetext{
*Corresponding author: lelabel@rambler.ru
} 
its prestige, forming both separate botanical areas located in the structure of palace and park ensembles, and the actual botanical gardens and botanical areas in the structure of public gardens.

By the end of the 19th century, a typological series of specialized architectural objects was formed, aimed at preserving plant collections, studying them, educating the population and organizing recreation places. The slogan of this time is Plants-Life-Culture. In the 19th century, joint-stock companies were organized and private capital was attracted to build public greenhouses.

In the conditions of modern society, historical greenhouses, regardless of their status, are an example of the evolution of architecture of this typological series, an object of cultural heritage in the field of architecture and botanical gardening that requires special attention.

The greenhouse can be considered one of the varieties of the garden, which has historically been a means of uniting man and nature, on the spiritual, aesthetic and material levels. In the West, the culture of botanical gardening has historically been at a high level, and this level has not been lost even today, the indicator is a large number of botanical gardens (France-113, Germany-90, etc. ), as well as large estates, villas and manors on the territory of which conserved greenhouses of the late 19th and early 20th centuries.

In this regard, it is interesting to study the experience of European countries that have influenced the development of world botanical architecture, such as Italy, France, Belgium, Austria and Germany, in the field of restoration and use of these historical structures.

\section{Materials and methods}

The subject of this research is the modern functional use of historical greenhouses in such European countries as Italy, France, Belgium, Austria and Germany.

Analysis of modern adaptation of greenhouses of European countries influenced the development of botanical gardening in Russia is carried out to determine the impact of new features on the preservation of the authenticity of the historical object. And also this analysis allows to identify specific architectural and design features of greenhouses, influencing the choice of functional use after restoration.

For this research, an activity-based (functional) approach was chosen, using an analytical method. To identify the General cultural significance of objects of botanical gardening, the historical and cultural method was also used.

The material for this study was photographic, iconographic, statistical materials and electronic resources related to this object, as well as the work of A. Baraton, Yves-Marie Allain, R. Barbault, Yvon Comte considering greenhouses in the historical aspect.

\section{Results and discussion}

\subsection{Historical analysis of changes in the basic function of greenhouses}

Historical analysis has revealed two groups of reasons that changed the basic botanical function of greenhouses these are:

- $\quad$ global: military conflicts, social upheavals, economic instability;

- local: financial failure of the owner, change of owner, loss of interest in this topic.

On the example of greenhouses in such European countries as France (A. Baraton, 2010), Austria (Yu. Sasi. 2009), Germany (Korovin, 1959), Belgium (P. Boxus, 1994) and Italy (L. Gratani, 2010) demonstrate the historical functional transformations of the object of botanical gardening and their causes (table 1).numbers. 
Table 1. Historical and functional transformation of the object of Botanical horticulture.

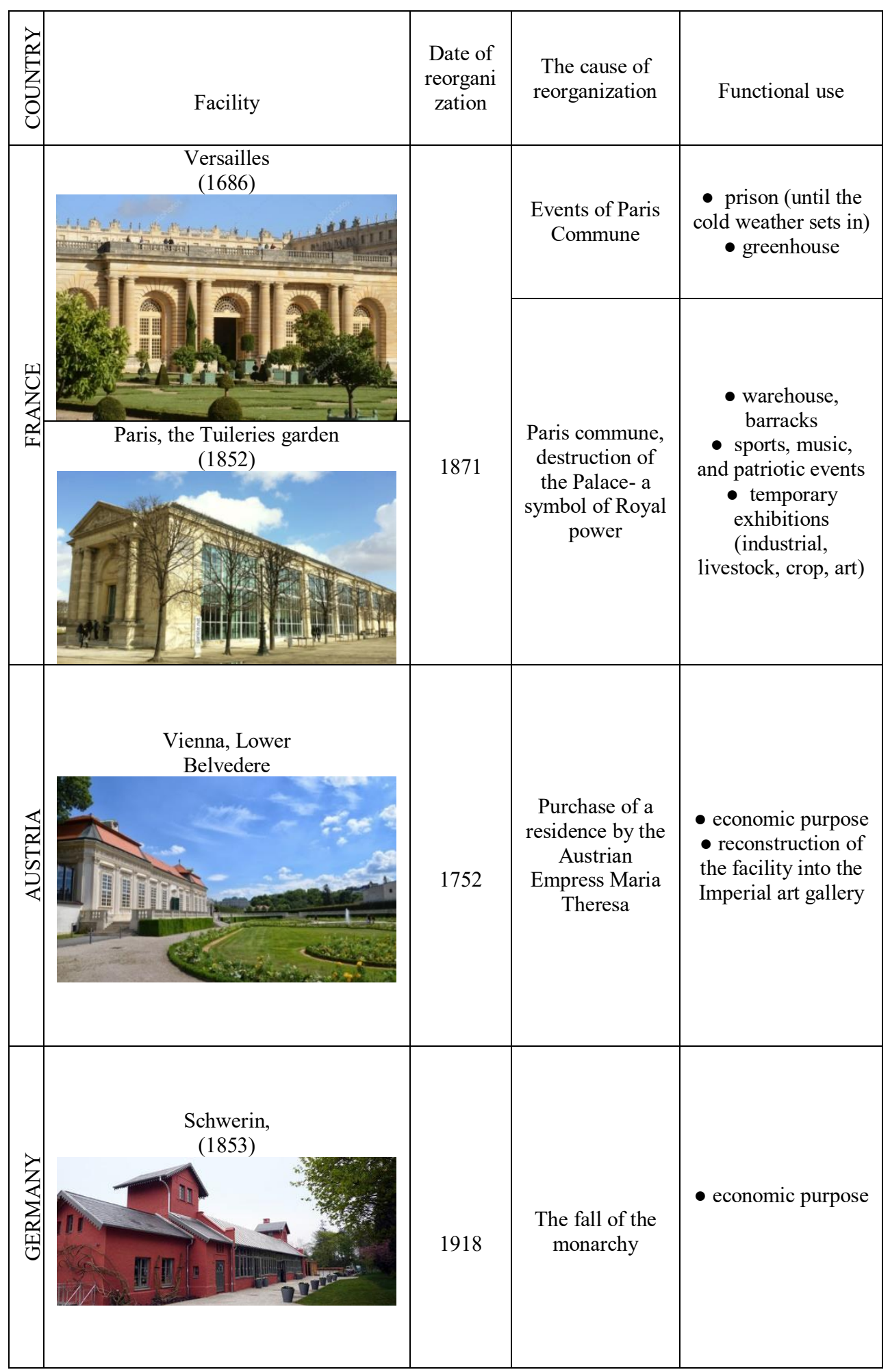




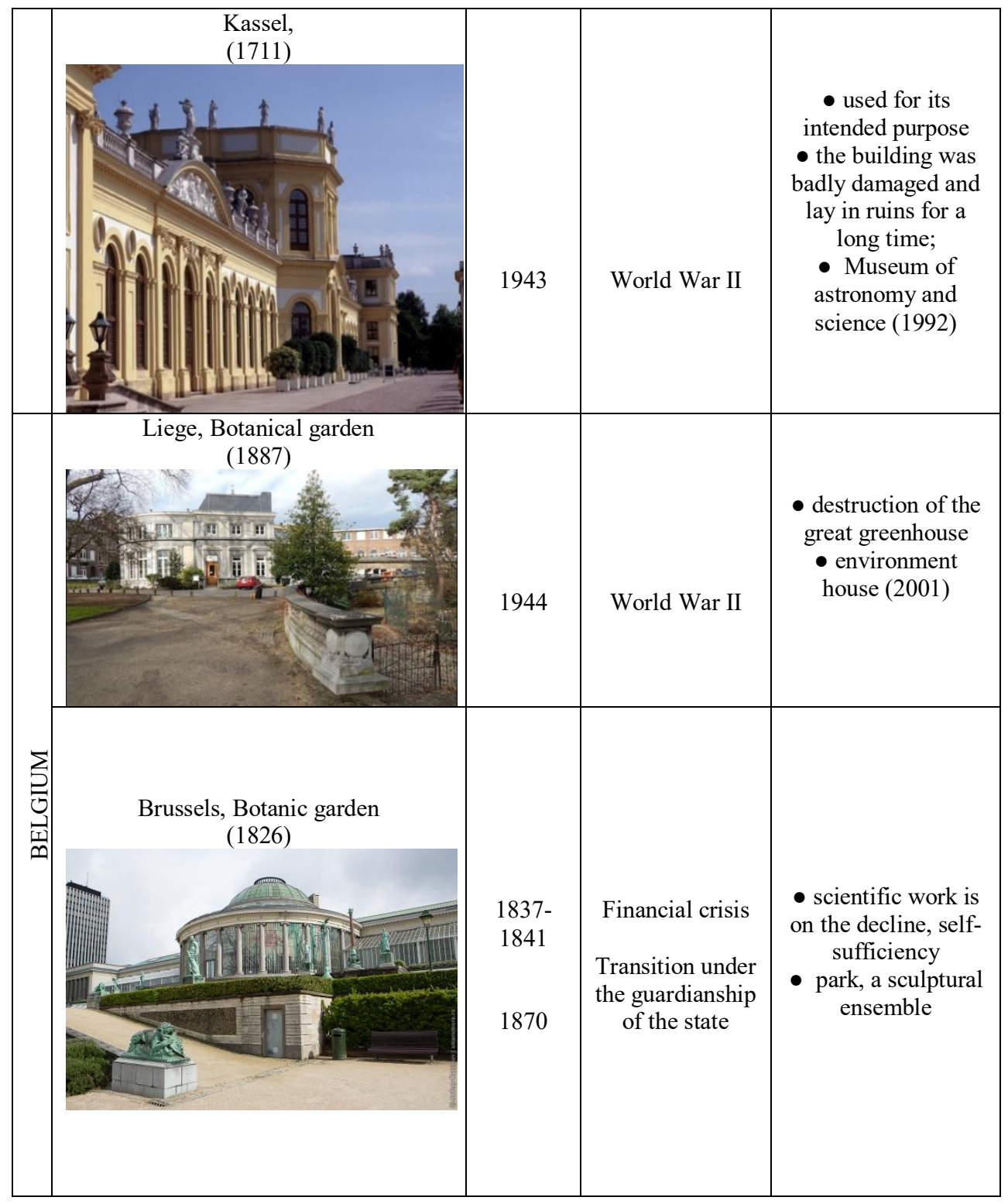




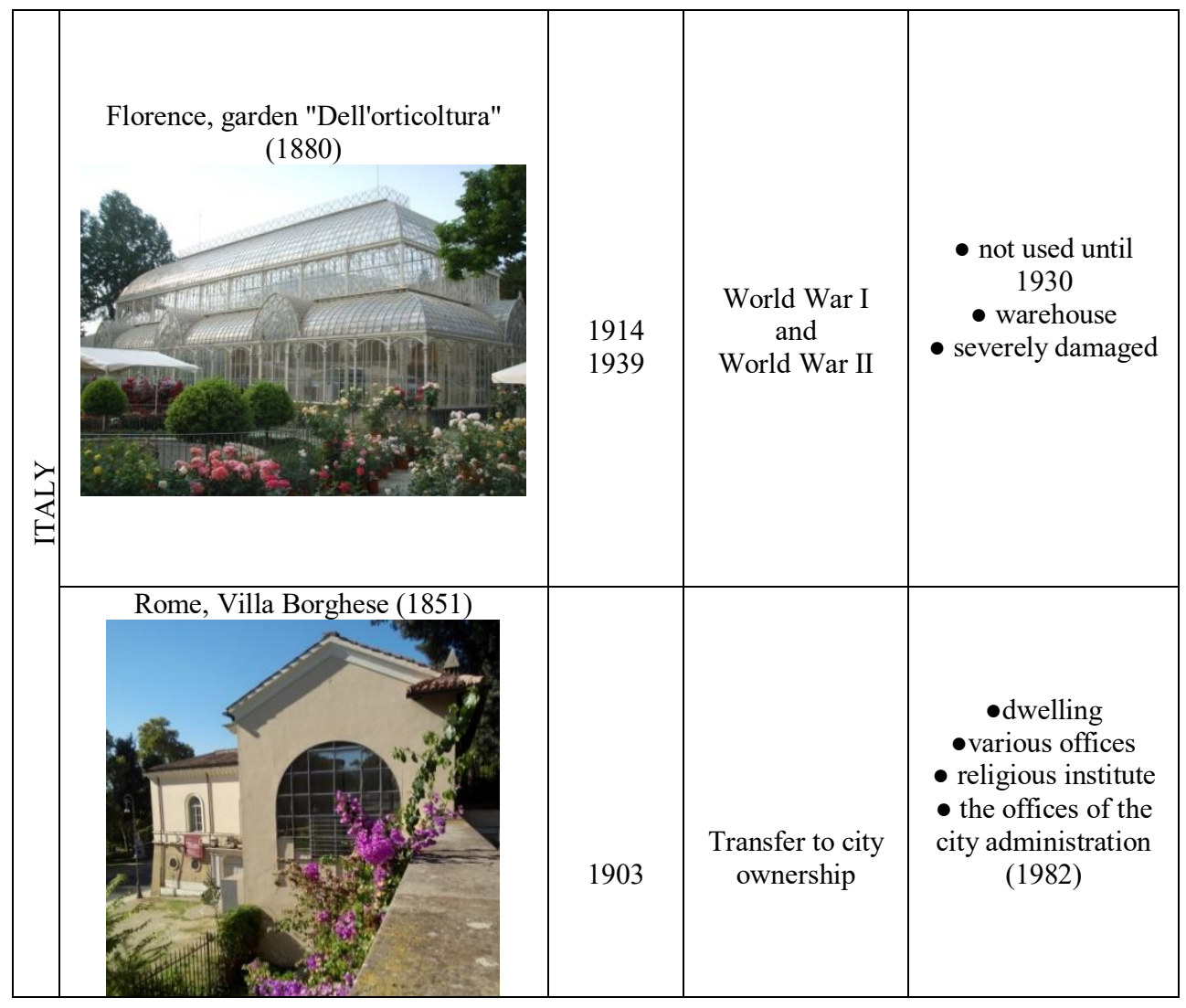

With World War I, the decline in the development of horticultural societies begins, some botanical gardens become the property of the city and become public gardens (Italy, Belgium). Some orangeries are either not used or are not used for their intended purpose. Architectural objects of botanical gardening suffered significant damage during World War II, which later influenced the change in the status of some botanical gardens.

For example, in the city of Liege, the loss of the dominant greenhouse complex and its further conservation led to the transfer of the territory to the status of an urban garden and the transfer of the botanical garden to a new location. Historical events and trends in the development of modern society aimed at the exploitation of wildlife resources have led to the fact that the interest of a wide range of people in greenhouses by the middle of the 20th century has declined, they are beginning to be perceived mainly from a practical, utilitarian point of view. The greenhouses of many historical estates, as well as the estates themselves, are losing their former appearance. The expansion of botanical gardens and their transfer to free territories partly contribute to the preservation of manor greenhouses, but not always returning them to their basic botanical function.

The analysis of restoration and reconstruction of historical greenhouses (table 2) showed that only since the second half of the 20th century, historical greenhouses again attract attention as objects of cultural, architectural and environmental heritage.

Table 2. Restoration and reconstruction of historical greenhouses. 


\begin{tabular}{|c|c|c|c|c|c|}
\hline Country & \multicolumn{2}{|c|}{$\begin{array}{l}\text { Historical status of the urban } \\
\text { planning structure }\end{array}$} & $\begin{array}{c}\text { Date of } \\
\text { construction }\end{array}$ & Modern use & Date of renovation \\
\hline \multirow{6}{*}{ France } & \multicolumn{2}{|c|}{ The Cheverny Castle } & XVIII century & $\begin{array}{l}\text { congresses, } \\
\text { seminars, } \\
\text { wedding }\end{array}$ & $\begin{array}{l}1979 \\
\text { restoration and }\end{array}$ \\
\hline & \multirow{3}{*}{ Paris } & $\begin{array}{l}\text { Botanical } \\
\text { garden }\end{array}$ & 1836 & $\begin{array}{c}\text { excursions } \\
\text { scientific research }\end{array}$ & $\begin{array}{l}2005-2010 \\
\text { renovation }\end{array}$ \\
\hline & & $\begin{array}{c}\text { The } \\
\text { Luxembourg } \\
\text { garden, urban } \\
\text { garden }\end{array}$ & 1830 & $\begin{array}{l}\text { the museum, } \\
\text { orangery } \\
\text { temporary } \\
\text { exhibitions }\end{array}$ & 1986 \\
\hline & & $\begin{array}{c}\text { Tuileries } \\
\text { garden, city } \\
\text { garden } \\
\end{array}$ & 1852 & art museum & $\begin{array}{c}1960-2006 \\
\text { four stages of } \\
\text { reconstruction }\end{array}$ \\
\hline & \multicolumn{2}{|c|}{$\begin{array}{c}\text { The estate of Bonrepos } \\
\text { Riquet }\end{array}$} & 1780 & $\begin{array}{l}\text { seminars } \\
\text { concerts } \\
\text { exhibitions }\end{array}$ & $2019-2020$ \\
\hline & \multicolumn{2}{|c|}{ Tallis-a-Duclair castle } & 1870 & greenhouse & $2019-2020$ \\
\hline Austria & Bur & $\begin{array}{l}\text { ienna } \\
\text { ten, gardens }\end{array}$ & 1901-1906 & $\begin{array}{l}\text { cafe restaurant, } \\
\text { garden of } \\
\text { butterflies, } \\
\text { winter garden }\end{array}$ & $\begin{array}{l}1996-1998 \\
\text { complex } \\
\text { restoration }\end{array}$ \\
\hline \multirow{4}{*}{ Germany } & \multicolumn{2}{|c|}{$\begin{array}{c}\text { Cologne } \\
\text { Flora Botanical Garden }\end{array}$} & 1864 & $\begin{array}{c}\text { excursions } \\
\text { scientific research }\end{array}$ & $\begin{array}{c}1945-1949 \\
\text { restoration works } \\
1964 \text { - complete } \\
\text { of restoration } \\
\text { works } \\
\end{array}$ \\
\hline & \multicolumn{2}{|c|}{$\begin{array}{l}\text { Schwerin } \\
\text { gardens }\end{array}$} & 1853 & $\begin{array}{l}\text { exhibition hall } \\
\text { offices }\end{array}$ & $\begin{array}{c}2009 \\
\text { completion of the } \\
\text { reconstruction }\end{array}$ \\
\hline & \multicolumn{2}{|c|}{ Kassel } & 1886 & $\begin{array}{c}\text { Museum of } \\
\text { astronomy and } \\
\text { science } \\
\end{array}$ & $\begin{array}{l}1992 \\
\text { reconstruction }\end{array}$ \\
\hline & \multicolumn{2}{|c|}{ Greifswald } & $\begin{array}{l}\text { the end of } \\
\text { 19th century }\end{array}$ & greenhouses & $\begin{array}{l}\text { 2014-2020 } \\
\text { restoration works }\end{array}$ \\
\hline Belgium & \multicolumn{2}{|c|}{$\begin{array}{c}\text { Brussels } \\
\text { «Le Botanique», } \\
\text { city garden }\end{array}$} & 1829 & cultural center & 1984 \\
\hline \multirow{7}{*}{ Italy } & \multicolumn{2}{|c|}{$\begin{array}{c}\text { Florence } \\
\text { «Giardino dell’Orticultura» } \\
\text { city garden }\end{array}$} & 1880 & $\begin{array}{c}\text { multipurpose } \\
\text { exhibition space }\end{array}$ & $\begin{array}{c}2000 \\
\text { completion of } \\
\text { complex } \\
\text { restoration } \\
\end{array}$ \\
\hline & \multirow{3}{*}{ Рим } & Villa Borghese & 1851 & $\begin{array}{c}\text { modern art } \\
\text { museum }\end{array}$ & $\begin{array}{l}2006 \text { restoration } \\
\text { and adaptation }\end{array}$ \\
\hline & & Villa Torlonia & & cafe & $\begin{array}{l}1978-2014 \\
\text { restoration } \\
\end{array}$ \\
\hline & & $\begin{array}{c}\text { Botanical } \\
\text { garden }\end{array}$ & 1930 & conference hall & 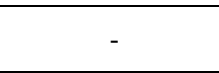 \\
\hline & \multicolumn{2}{|c|}{ Villa Grumello-Como } & $\begin{array}{l}\text { the end of } \\
\text { 19th century }\end{array}$ & $\begin{array}{c}\text { exhibition } \\
\text { greenhouse } \\
\text { cafe } \\
\end{array}$ & $\begin{array}{l}2012 \\
\text { reconstruction }\end{array}$ \\
\hline & \multicolumn{2}{|c|}{ Villa Olmo } & 1883 & greenhouse & $\begin{array}{c}2019 \\
\text { project of } \\
\text { restoration }\end{array}$ \\
\hline & Meina & Villa Faragina & $\begin{array}{l}\text { the end of } \\
\text { 19th century }\end{array}$ & $\begin{array}{l}\text { greenhouse } \\
\text { exhibitions }\end{array}$ & $\begin{array}{c}2018 \\
\text { completion of } \\
\text { restoration }\end{array}$ \\
\hline
\end{tabular}




\subsection{Contemporary use of the historic greenhouses}

The In the 21st century, Western European countries have increased their attention to the problems of ecology and environmental conservation (the biodiversity conservation program). In this regard, more attention has been paid to the problems of preserving, restoring and adapting historical greenhouses located both on the territories of botanical gardens and on the territories of Palace and Park ensembles, as well as the construction of new innovative architectural objects of botanical gardening. Botanic gardens first of all took care of the state of architectural heritage in this area. For example, in France, according to the survey of botanical gardens conducted in 2010 by OPCST-OCIM, the total area of all collection and exhibition greenhouses is $40,000 \mathrm{~m} 2$.

Public funds and public organizations are involved in the preservation of architectural heritage, such as the Heritage Foundation - the first private organization in France, established in 1996, which carries out its protection activities, primarily of objects that are not protected by the state, through charitable donations from individuals, companies and territorial bodies and associations. In the city of Nantes, a Biodiversity Council was established in 2010 to guarantee the conservation of urban biodiversity.

In Germany, the organization BUGA (exhibitions of garden and Park design) aims to transform degraded urban areas, as well as to restore historical Palace and Park ensembles and restore their former splendour, which has become a priority in recent years. The restoration of the complex of historic greenhouses of the botanical garden in Greifswald (2014-2020) has comprehensive funding (state, Federal government, University's own funds and private investment, www.ostsee-zeitung.de/Vorpommern/Greifswald/Sanierungder-historischen-Gewaechshaeuser-in-Greifswald).

Gradually, the problems of preserving historical and cultural heritage in the field of botanical gardening began to come to the fore, which helped to find solutions for adapting historical greenhouses to modern requirements. The first restoration works were carried out after the Second World War, during which bright examples (Strasbourg, Liege) of the architecture of botanical gardening of the early 20th century were damaged or completely destroyed. The policy of European countries provides for the preservation of the object of botanical gardening, as well as the implementation of educational, learning, scientific and cultural functions that emphasize the role of these objects in the formation of the status of both the city and the country as a whole. The resumption of horticultural exhibitions also contributes to the restoration of greenhouses (Kassel-1955, Schwerin-2009).

In world practice there are two vectors of development of various historical objects:

- influence on the functional purpose of the object;

- influence on the architectural and spatial organization of the object.

The conversion of architectural objects of botanical gardening in the West is mainly along the first path of development, affecting their functional use.

65 historical greenhouses located on the territory of botanical gardens, as well as on the territory of palace and park ensembles, estates and villas in France, Germany, Austria, Belgium and Italy were considered for modern use. This study (table 3) allows us to identify three areas of their functional use:

- preserving the basic botanical function;

- changing the basic botanic function;

- combination of different functions.

In Europe, the creation of new and preservation of already existing botanical horticulture facilities for various purposes and status is one of the main methods of transforming and improving the urban environment. In modern conditions, the historically established botanical garden does not exist in isolation, only as a scientific institution. European countries have developed an effective model of its functioning, which allows to 
involve different segments of the population, taking into account their needs both economic and aesthetic. Which in turn has an impact on the definition of the new function.

Table 3. Functional use of historical greenhouses.

\begin{tabular}{|c|c|c|c|c|c|c|c|c|c|c|}
\hline Country & \multicolumn{10}{|c|}{ Basic botanical function } \\
\hline & \multirow[b]{2}{*}{ 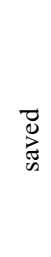 } & \multicolumn{5}{|c|}{ Changed } & \multicolumn{4}{|c|}{$\mathrm{C}=$ Combined } \\
\hline & & $\begin{array}{l}\bar{\pi} \\
\stackrel{\Xi}{0} \\
. \Xi\end{array}$ & 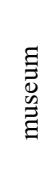 & $\stackrel{\mathscr{J}}{\tilde{J}}$ & 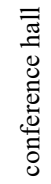 & 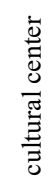 & $\begin{array}{l}\stackrel{\vec{J}}{0} \\
. \cong\end{array}$ & 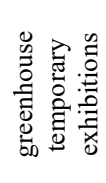 & 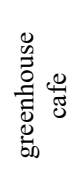 & 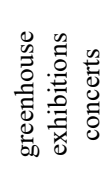 \\
\hline FRANCE & 9 & 5 & 2 & 1 & 2 & - & 1 & 2 & - & - \\
\hline $\begin{array}{c}\text { GERMA } \\
\text { NY } \\
\end{array}$ & 6 & 4 & 3 & - & 1 & - & 3 & 2 & 1 & - \\
\hline $\begin{array}{c}\text { AUSTRI } \\
\text { A } \\
\end{array}$ & 3 & 2 & - & 1 & 1 & - & 2 & - & 1 & - \\
\hline $\begin{array}{c}\text { BELGIU } \\
\mathrm{M}\end{array}$ & 3 & 3 & 1 & 1 & - & 1 & - & - & - & - \\
\hline ITALY & 13 & 4 & 1 & 2 & 1 & - & 6 & 3 & 2 & 1 \\
\hline in total & 34 & 18 & 7 & 5 & 5 & 1 & 12 & 7 & 4 & 1 \\
\hline total & & & & & & & & & & \\
\hline
\end{tabular}

\section{botanical function}

\ combined \|changed \| persisted

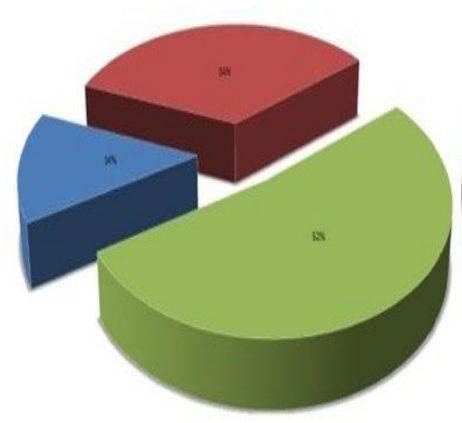

changed function

\museums 【cafe 『conference hall |conference hall

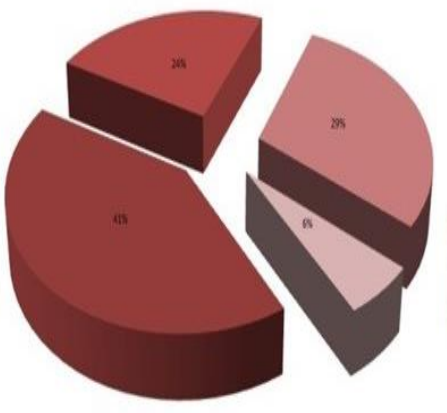

\section{combined function}

greenhouse - restaurant

- temporary exhibitions - greenhouse II concert hall-temporary exhibitions-orangery

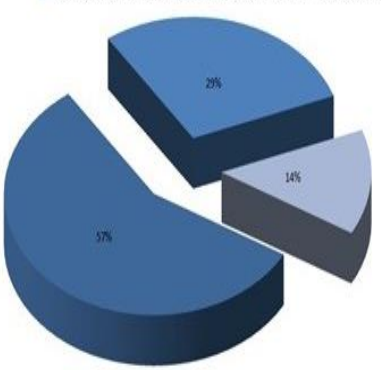

Fig. 1. Conversion options for architectural objects of botanical horticulture.

From the scheme shown above (Figure 1), it can be seen that the basic botanical function $(52 \%)$ dominates in the restoration and adaptation of historical greenhouses, a significant proportion is the total change in initial use (34\%) and only a small proportion of the objects $(14 \%)$ have a combined function. Although the combination of botanical function with others is more attractive in adaptation than its complete change, since such a combination less affects the change in authenticity of historical greenhouse and allows to satisfy social needs of the population.

Changes in the functional use of greenhouses are carried out in 4 areas: museums, organization of public catering, conference centers, cultural centers. Combined use involves partial preservation of the basic function, the use of exotic landscaping in the interior of a cafe-restaurant, exhibition or concert hall. 


\subsection{Architectural and urban planning features of the facility}

\subsubsection{Location on the site}

Mostly, this is one greenhouse from the group, which is a separate object located on the border of the site, shifted towards the center or forming a single composite structure with the Palace complex, with conveniently organized access.

It is a significant architectural unit of a given site and its accent. When changing the function of the object, the layout and floristic design of the garden area adjacent to the greenhouse is preserved using exotic plants in pots, which is a reminder of the basic botanical function of the object and is aimed at maintaining a special architectural and environmental perception of its exterior at the changed interior (Figure 2).
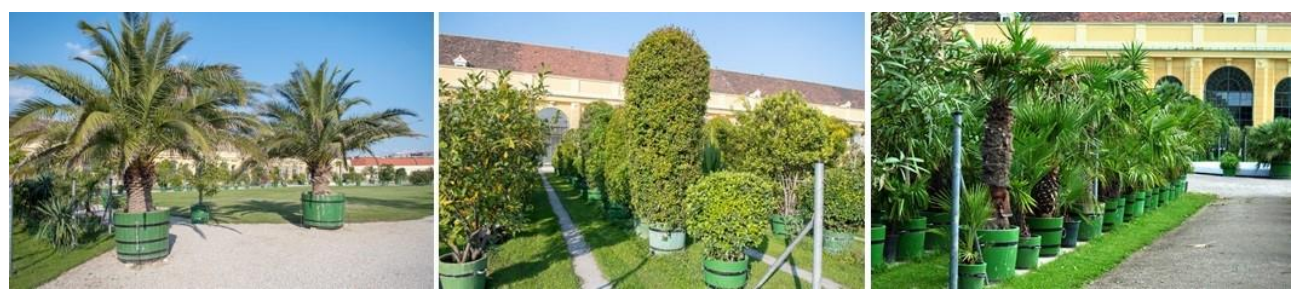

Fig. 2. Design of the garden area adjacent to the greenhouse.

In some cases, the space in front of the greenhouse is actively used for various exhibitions, shows and screenings, as well as open-air concerts. Objects located on the terrain (Burggarten, Vienna) make it possible to organize a new function with minimal interference in the interior space, since the lower level is used for utility rooms. Also, directly on the territory or adjacent to it, there are operating greenhouses (Vienna, lower Belvedere, Schoenbrunn).

\subsubsection{Geometric characteristics and material of the greenhouse}

Greenhouses are divided into small (height up to $4 \mathrm{~m}$ ), medium (height up to $7 \mathrm{~m}$ ) and large (height more than $7 \mathrm{~m}$ ). First of all, medium ones are subject to conversion, less often large and small. These are simple, one-story, rectangular in plan, often single-span buildings with load- bearing longitudinal walls without additional internal supports, made mainly of stone. It can also be three-part stone structures with two-story side volumes and a greenhouse onestory hall in the center, or rectangular in plan buildings made in a combination of stonemetal or metal frame with additional supports that form a three-part division of the interior space.

Taking into account the climatic conditions, in European countries, it was necessary to set up greenhouses for seasonal, temporary placement of exotic plants in tubs designed to decorate the space of the garden and the Palace. In this regard, the internal space of the greenhouses had a significant area with a solid stone floor covering and could be used in the summer as a backroom space, ideal for holding lavish celebrations and musical performances (Berlin Charlottenburg). This type of greenhouse has historically been a multifunctional object.

\subsubsection{Architectural and environmental impression}

The following table 4 shows the options for modern functional use of greenhouses, let's consider them in more detail. 


\section{Changed the function.}

The most common adaptations of greenhouses - cafes, exhibition halls or conference rooms, mainly preserve the appearance and use the interior space of the object, without changing its geometric characteristics, which is very important, because there is always a question of reversibility when adapting a historical object. Such objects become commercially attractive, their material authenticity is not reduced, since it does not require interior remodelling. The capacity of the considered objects in the conditions of modern use as a concert or conference hall is from 300-800 seats.

The modern use of greenhouses for classical concerts, opera and even ballet, as in Schoenbrunn, partially changes the architectural and environmental impression of the object due to the lack of landscaping in the interior design, which is compensated by the design of the exterior space.

Museumification is another option for adapting historical greenhouses, which involves preserving their architectural forms. At the same time, the organization of the Museum's exhibition space of any profile (art, astronomy, etc.) completely changes the impression of the greenhouse interior, since there is a contradiction between the external form and the internal content of the object, and the balance of aesthetic values changes. Also, conversion to a museum may require significant modernization of an object. An example of this conversion is the Orangery Museum in Paris, where the expansion of the collection required modernization and development of the underground part of the object, while preserving only its appearance and dimensions. In this case, we can talk about the transition of the historical object of botanical gardening to another typological architectural series that forms a new socio-cultural environment.

2. Combined function.

The most profitable in modern conditions, since the basic botanical function is partially preserved and combined with commercially attractive functions, first of all, catering, then the organization of temporary exhibitions, flash mobs, and ceremonies, which does not require significant modernization of the object.

This use is possible if the historical greenhouses have several volumes in their composition that allow you to distribute the functional zones. In this case, the exotic plants of the greenhouse become elements of interior design, preserving the special atmosphere, its historical and aesthetic value.

\section{Preserved function.}

Only the preservation of the basic function can fully demonstrate the historical and aesthetic value of greenhouses, since it is the floral composition and characteristics of plants that directly influenced the shape and size of the greenhouse, creating a special combination of architecture and nature.

Large historical metal structures have been preserved in the territories of the botanical gardens. Their restoration involves both preserving the historical appearance of the object, its details, and functional use, taking into account both the requirements for the objects themselves and the desire to make them accessible to all segments of the population. In this case, work is underway to change the direction of the exhibition space, while preserving its potential and re- equipment - in combination with changing the museography, which allows us to solve current issues and raise public awareness.

Small greenhouses are both part of the overall composition of the botanical garden, and an integral part of the botanical areas of many Park ensembles and are mainly used for their intended purpose, which contributes to the preservation and promotion of greenhouses. This process is more active in France and Italy, where the preservation of small, medium and large greenhouses is aimed at improving the environment, creating accessible places for learning and recreation, as well as organizing a space with an exceptional perception of the place. 
Table 4. Architectural and environmental impression (interior).

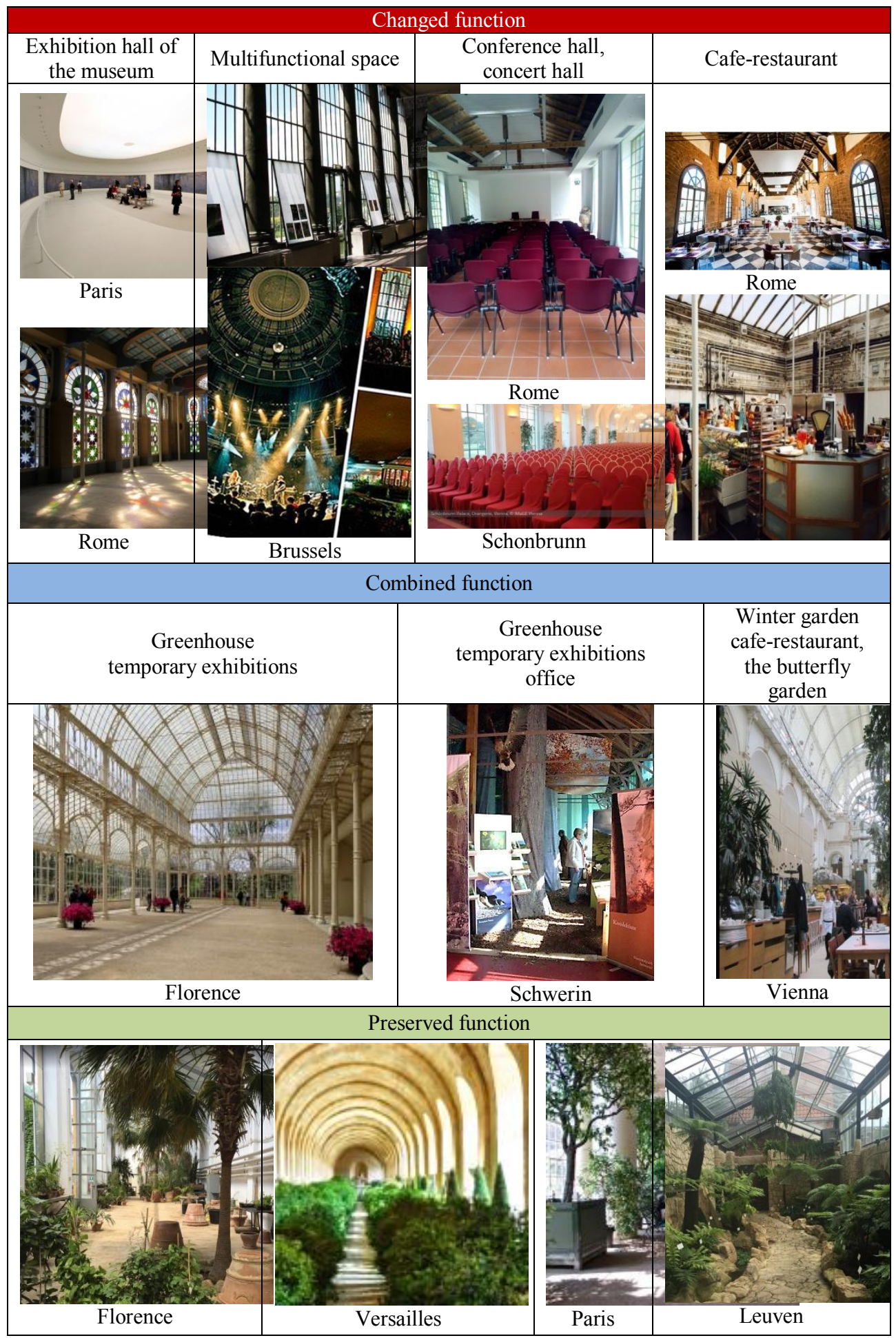




\section{Conclusion}

The analysis of the functional use of greenhouses of various status has revealed that since the beginning of the 21 st century, historical greenhouses have reached a new level of their value perception:

- as a sample of Botanical architecture and an element without which there is no complete perception of garden and Park complexes of various status;

-as a historical object that demonstrates the past success and financial viability of the owners, which allowed them to set up Botanical gardens and maintain the richest collection of greenhouses;

-as an object that increases the status of the territory and its tourist attractiveness, both for indigenous residents and for guests;

-as a venue for cultural events of various levels, training and recreation.

The analysis also showed various techniques in solving the problem of adapting historical greenhouses to modern use, which, while preserving the historical architecturalplastic solution, ambiguously affect the preservation of the architectural and environmental perception of the object. Thus, changing the function leads to a violation of the balance of external and internal perception of the object (without additional conditions), while preserving and combining the basic function does not distort it.

The issue of preservation, restoration and adaptation of cultural heritage objects in the botanical sphere, which include greenhouse areas, greenhouse complexes and greenhouse areas of winter gardens, is problematic in St. Petersburg due to the established opinion on their utilitarian and economic inefficiency in the modern conditions of development of the city. The study of foreign experience, in solving this issue, is aimed at changing opinion on this problem and attracting the attention of potential investors of Russia to the restoration of historical greenhouse areas, as a category of objects, with scientific, educational and cultural functions having huge tourist attractiveness.

\section{References}

1. R. Barbault, J. Pl. Mus (2010)

2. Y.-M. Allain, Hist. Bot. (2014)

3. Yu. Sasi., V. Hist. Cit.(2009)

4. P. Boxus, J. Hist. Sc. Cult., 39, 328, 4-33 (1994)

5. L. Gratani, Palom. Part. SrlRom. (2010)

6. https://www.fondation-patrimoine.org/les-projets/serre-du-chateau-du-taillis-a-duclair (accessed 28.02.2020)

7. https://www.fondation-patrimoine.org/les-projets/orangerie-et-maison-du-jardinier-dudomaine-de-bonrepos-riquet (accessed 10.02.2020)

8. https://www.ostsee-zeitung.de/Vorpommern/Greifswald/Sanierung-der-historischenGewaechshaeuser-in-Greifswald (accessed 18.02.2020)

9. http://www.effetrefotostudio.com/villa-del-grumello-como/ (accessed 18.02.2020)

10. https://www.museomeina.it/il-restauro-delle-serre-di-villa-faraggiana-a-meina/ (accessed 18.02.2020)

11. http://www.legifrance.gouv.fr (accessed 18.02.2020)

12. J.N. Belvedere, Vienn, 4 (2019) 